\title{
BIMBINGAN DAN KONSELING ISLAM \\ DALAM MENINGKATKAN RELIGIUSITAS SISWA \\ SEKOLAH MENENGAH ATAS (SMA)
}

\author{
Kuliyatun \\ Universitas Muhmmadiyah Metro \\ Kuliyatun1971@gmai.com
}

\begin{abstract}
The existence of Islamic guidance and counseling services at school can be used as a method by teachers in providing guidance and motivation to students in accordance with the teachings of the Qur'an and Hadith by applying religious values as a guide or foundation for students in overcoming all the problems they face. Lack of religious understanding is one of the factors that lead to deviant behavior towards adolescents, it can occur when individuals do not have a strong religious foundation so they are easily affected by environmental conditions, so there is a need for a process of mentoring learning and religious education. Guidance and counseling in the view of Islam is an effort made to solve a problem that occurs in a person based on Islamic norms. Based on the function of Counseling Guidance in the Islamic view of everything that is done in order to enrich the potential of the students and try as much as possible to find out what is being experienced in order to obtain the right solution and have a life in God's favor both in the world and in yaumil end.
\end{abstract}

Keywoard: Guidance, Islamic Counseling, Religious 


\section{A. Pendahuluan}

Dimata Allah SWT manusialah makhluk yang diciptakanNya paling sempurna. Allah membekali manusia dengan tiga hal yaitu pikiran (akal) untuk berfikir, membekali hawa nafsu, dan perasaan (hati) untuk merasakan. tak lupa juga Allah memberikan manusia berupa hak untuk menjalani kehidupan sesuai dengan apa yang manusia itu harapkan, dengan begitu manusia bebas memilih antara mendapatkan kehidupan yang baik atau tidak baik. Allah membekali manusia sejak ia lahir kedunia dengan fitrah untuk melakukan perbuatan yang baik, sesuai dengan norma-norma yang berlaku di lingkungan masyarakat. Tetapi terkadang manusia akalnya, hatinya dan perasaannya mudah sekali terpengaruh terhadap norma-norma yang buruk di lingkungan tempat tinggalnya, sehingga hilanglah fitrahnya. Oleh sebab itu karena kecenderungan manusia yang dapat melakukan hal-hal kebaikan dan keburukan maka, Allah SWT menurunkan petunjuk berupa Agama Islam sebagai pedoman hidup dengan berlandaskan al-quran dan al-hadits. Apabila aturan yang ada di dalam Al-quran dan Al-hadits mampu ditaati dengan baik maka Surga adalah tempat bagi mereka gang taat, tetapi apabila aturan tersebut dilanggar maka neraka lah tempat bagi mereka. Manusia akan terhindar dari jalan kesesatan apabila ia mampu mempertebal iman dan selalu bertaqwa kepada Allah SWT1. Agama memuat simbol-simbol ketuhanan, memegang teguh keyakinan, memelihara nilainilai/norma, lalu terealisasi dengan tingkah laku dengan sebuah penghayatan. ${ }^{2}$

Perkembangan peserta didik tidak hanya dilihat dari fisik saja tetapi sikap keagamaannya yang diterapkan dalam kehidupan sehari-hari, sudah sesuai dengan pedoman agama atau belum karena ini hal yang penting untuk dibahas. Untuk membentuk kepribadian peserta didik yang sesuai dengan norma-norma agama yang berlaku membutuhkan upaya yang

1 Hemlan Elhany, Dakwah Islam Di Era Golbalisasi Perspektif Bimbingan Penyluhan Islam, Jurnal Bimbingan Penyuluhan Islam, Vol.1 No 1 Januari-Juni 2019 h 298

2 Ancok, Djamaludin. Psikologi Islam (Yogyakarta: Pustaka Pelajar, 1994), h. 76 
efektif agar output yang dihasilkan tidak menyimpang dari ajaran agama islam.

Ketika manusia tersebut memasuki fase remaja maka inilah yang dinamakan proses menuju kedewasaan. Masa remaja menjadi fase penting, mengingat bahwa pada fase inilah karakter dan kepribadian remaja terbentuk dalam mengenali dirinya sendiri. Pada masa ini remaja harus berada didalam pengawasan dan diarahkan secara maksimal menuju kehidupan sesungguhnya dengan dibekali ilmu pengetahuan agar dapat berbaur dengan sekitar. ${ }^{3}$ Kegiatan bimbingan konseling penting dilakukan dengan maksud untuk menumbuhkan sikap dan perilaku peserta didik menuju ke arah yang lebih baik dan meminimalisir terpengaruh oleh hal-hal yang kurang baik. Betapa pentingnya ilmu agama bagi peserta didik dalam pembentukan kepribadian, budi pekerti dan sikap untuk menekan angka kenakalan remaja yang berawal dari minimnya pengetahuan mereka tentang agama. Pengenalan agama bagi peserta didik diawali dengan pendidikan yang ada di dalam keluarga, disinilah seorang anak dibekali ilmu agama oleh orangtua/keluarganya. 4

Jika sejak awal peserta didik ini tidak dibekali dengan agama maka ia akan mudah terperosok ke dalam jalan kesesatan karena tidak ada arah tujuan yang dituju. Lingkungan merupakan tempat untuk bersosialisasi dengan berbagai macam individu, apabila lingkungan tersebut memiliki kecenderungan yang positif maka nilai-nilai keagamaan yang sudah diajarkan di dalam keluarga akan mudah terealisasi dengan baik, namun jika lingkungan tersebut cenderung ke arah yang negatif maka akan berdampak pula terhadap sikap dan perilaku peserta didik yang kurang baik atau bahkan lebih buruk. ${ }^{5}$ Pembentukan karakter sejak dini adalah sebuah upaya yang dilakukan agar peserta didik mampu mengenali dirinya sendiri.

3 Geldard, Kathryn dkk. Konseling Remaja Pendekatan Proaktif Untuk Anak Muda (Yogyakarta: Pustaka Belajar, 2010), h. 4

${ }^{4}$ Anton Widodo, Fathur Rohman, Konsep Jiwa Yang Tenang Dalam Surat Al-Fajr Ayat 27-30 (perspektif Bimbingan Konseling Islam), Al-Irsyad: Jurnal Bimbingan Konseling Islam, Vol.1 No 2 Desember 2019 h 232-233

5 Sutoyo, Anwar. Bimbingan dan Konseling Islami(teori dan praktik), (Yogyakarta: Pustaka Pelajar, 2013), h. 23 
Bimbingan konseling diberikan kepada setiap individu bukan hanya yang memiliki masalah umum seperti kehidupan sehari-hari tetapi secara menyeluruh baik dari aspek sosial dan keagamaan. Bisa dikatakan bahwa kegiatan bimbingan ini bila dilihat dari pandangan islam merupakan salah satu cara berdakwah. Dakwah adalah kegiatan keagamaan yang didalamnya terdapat ajakan dan menyeru kepada umat manusia untuk bersama-sama memerangi keburukan sesuai dengan jalan Allah SWT. Akibatnya jika tidak memiliki nilai dan norma-norma keagamaan maka seseorang melakukan hal-hal yang menyimpang dari ajarannya, oleh karena itu bimbingan sangatlah diperlukan untuk meningkatkan pemahaman keberagamaan atau religiusitas. Seseorang yang telah dibimbing diharapkan mampu meningkatkan keimanan dan kepatuhannya terhadap dzat yang Maha Kuasa. Patuh terhadap ketentuanketentuan yang sudah digariskan-Nya. ${ }^{6}$

Berdasarkan fungsi dari Bimbingan Konseling dalam pandangan islam yakni segala sesuatu yang dilakukan guna memperkaya potensi yang dimiliki peserta didik dan berusaha semaksimal mungkin untuk mengetahui apa saja yang sedang dialami agar dapat diperoleh solusi yang tepat dan memiliki kehidupan yang di ridhai Allah baik di dunia maupun di yaumil akhir.7 Selanjutnya pencegahan dan pembiasaan kepada peserta didik khususnya pada masa remaja dilakukan dengan cara ajakan untuk mendekatkan diri kepada Yang Maha Kuasa, dengan beriman maka akan dijauhkan dari hal-hal yang buruk, mendalami kaidah-kaidah keislaman, bertawakal inilah peran dari bimbingan dan konseling sesuai ajaran islam pada peserta didik di tingkat pendidikan Sekolah Lanjutan Tingkat Atas.

Pada masa remaja, individu mengalami banyak sekali halhal yang dapat mempengaruhi perkembangan fisik dan psikologisnya. Masa peralihan ini berawal dari masa anak-anak menuju masa dewasa dengan rentang tahun antara 11 sampai 21 tahun, inilah yang dinamakan masa remaja. Masa remaja adalah masa dimana individu senang dengan hal-hal baru dalam hidupnya yang terkadang melampaui takaran seusianya. Masa remaja identik dengan jiwa-jiwa muda yang menggebu-gebu,

\footnotetext{
${ }^{6}$ Ibid., h. 25

7 Ibid., h. 214
} 
bersikap dan berperilaku yang berlebihan, sikap seperti ini dapat menjadi bumerang terhadap remaja. Misalnya sering ditemui permasalahan di lingkungan sekolah peserta didik yang menginjak usia remaja dimulai dari tingkat pendidikan Sekolah Menengah Pertama menuju Sekolah Menengah Atas yang bersikap menyimpang, seperti membolos, membangkang kepada guru, merokok, minum-minuman keras, bahkan kasus terberat seperti mengunakan narkoba baik di lingkungan sekolah maupun di luar lingkungan sekolah. ${ }^{8}$ Lembaga pendidikan seperti sekolah diharapkan mampu menerapkan bimbingan dan konnseling baik di sekolah umum maupun sekolah berbasis agama. Sekolah juga memiliki peran penting terhadap pembentukan sikap dan perilaku peserta didik selain di dalam keluarga.

Walaupun nilai-nilai agama telah diajarkan dengan baik di dalam keluarga namun untuk menjangkau pengetahuan yang lebih luas lagi diperlukan lembaga pendidikan dengan adanya para pendidik yang membimbing dan mengarahkan agar pesera didik tetap berpegang teguh pada pedoman umat islam yakni alqur'an dan al-hadits. Diperoleh hasil penelitian yang dilakukan pada Di Sekolah Menengah Atas (SMA) mengenai proses bimbingan konseling berbasis islam. Pada lembaga tersebut para peserta didik kurang diajarkan tentang ilmu-ilmu keislaman yang lebih intens dibandingkan lembaga pendidikan islam lain dengan berbasis pondok pesantren tidak hanya ilmu agama saja tetapi juga ilmu umum.

Kelebihan yang dimiliki lembaga sekolah berbasis pondok pesantren adalah soal memperdalam di bidang agama, peserta didik diarahkan untuk menjadi pribadi yang shalih shalihah, mampu menjaga imannya, dan mampu mencari solusi apapun yang sedang dihadapinya melalui Bimbingan Konseling Islam di sekolah. Peserta didik yang ada di SMA ini memiliki latar belakang keluarga yang berbeda-beda, ada yang berasal dari keluarga berada dan tinggal di lingkungan perkotaan sehingga banyak permasalahan yang terjadi seperti kasus anak yang ditinggal pergi oleh ayah dan ibunya akibat perceraian dalam rumah tangga, anak yang ditelantarkan oleh kedua orangtuanya

8 Hikmawati, Fenti. Bimbingan Konseling(edisi Revisi), (Jakarta: Rajawali Pers, 2012), h. 24 
akibat masalah ekonomi yang tidak baik, sehingga dari beberapa hal yang terjadi didapati anak menjadi pribadi yang tertutup, arogan, labil dalam emosi, sikap yang sulit untuk dikendalikan, tidak mendapatkan kehangatan keluarga dan kasih sayang yang utuh dan yang paling buruk lagi anak tersebut dapat kehilangan keimanannya. Namun ada pula peserta didik yang berasal dari keluarga yang utuh tanpa ada permasalahan seperti yang disebutkan di atas.

Indonesia adalah negara yang kaya akan pulau-pulau dan wilayah yang luas, peserta didik yang berada Jenjang Sekolah Menengah Atas (SMA) yang mana yang mana siswa berasal berasal dari berbagai macam daerah, sudah barang tentu santrisantri tersebut membawa kultur dari daerahnya masing-masing keanekaragaman berbahasa dan lingkungan tempat tinggalnyapun berbeda-beda. Kebiasaan yang dibawanya tentu berbeda, ada yang cenderung ke arah baik adapula yang condong ke arah negatif, maka di Sekolah Menengah Atas (SMA) inilah diharapkan mereka akan mendapatkan kembali kebahagiaan dirinya, dengan mengisi hari-harinya melakukan kegiatan yang bermanfaat. Banyak hal yang mungkin belum pernah mereka dapatkan selama berada di lingkungan tempat tinggalnya, lain halnya di Sekolah Menengah Atas (SMA) mereka dapat mengeksplor lebih jauh tentang pemahaman mereka tentang agama islam. Seperti pemantapan imannya kepada Allah serta mampu menanamkan di dalam jiwanya, mengimani malaikat-malaikat Allah, kitab Allah yakni Al-qur'an, percaya akan adanya rasul kekasih Allah, percaya akan terjadinya hari kiamat kelak, percaya pada ketetapan Allah (Qada) dan apa yang telah Allah tentukan sejak zaman azali (Qadar).

Mengenai ajaran agama islam Allah SWT memberikan petunjuk berupa perintah kepada seluruh umat muslim untuk mendirikan shalat yang termuat dalam alqur' an surat al-isra ayat 78, adapaun sholat seperti wajib maupun shalat sunnah. Kemudian perintah untuk berpuasa yang termuat dalam surat albaqarah ayat 183-187 dan ayatayat lain dalam Al-Qur'an. Jika dikaitkan dengan realitas remaja cenderung menempati posisi yang rentan akan terjadinya penyimpangan pengaruh dari lingkungan yang kurang baik, seperti perilakunya ketika berhadapan dengan orang yang usianya lebih tua atau lawan 
bicara dengan teman seumurnya yang terkadang tidak sesuai nilai kesopanan. Kecenderungan tersebut dapat terjadi ketika peserta didik tidak dibimbing dengan baik dan rata-rata hal ini terjadi pada usia 13-15 tahun, sehingga dapat berlanjut hingga pada usia 16-18 tahun.

Penyimpangan yang terjadi harus berangsur-angsur ditangani agar mereka memiliki semangat untuk terus belajar memperbaiki diri, disinilah peran bimbingna konseling islam di Sekolah Menengah Atas (SMA)ini sangat berpengaruh terhadap perubahan perilaku peserta didik agar tidak ada lagi yang bersikap menyimpang seperti, enggan untuk melaksanakan sholat berjamaah, malas untuk puasa wajib maupun sunnah, tidak suka ikut tadarus bersama, tidak memiliki sikap rendah hati, tidak sopan terhadap guru. Diharapkan dengan bimbingan yang diterapkan mampu memperbaiki nilai-nilai peserta didik menuju ke arah yang lebih baik, dengan gemar membaca AlQur'an atau menjadi hafiz, shalat wajib dan sunahnya selalu terjaga, menjadi santun dalam bersikap berbicara juga sopan tidak hanya dengan kawan sebaya tetapi dengan guru atau ustadz juga orang tua.

Kalau lembaga pendidikan yang tidak berbasis ponpes dalam memantau peserta didiknya terbatas hanya pada jam sekolah saja, tidak demikian dengan Siswa SMA ini, karena ruanglingkup Sekolah Menengah Atas (SMA)berada pada satu wilayah maka untuk pemantauan peserta didik dapat dilakukan secara penuh dari mulai pagi sampai malam hari yang diinstruksikan langsung kepada seluruh jajaran pendidik ataupun staf di Siswa SMA. Hal ini bukan dimaksudkan untuk membatasi ruang gerak peserta didik tetapi untuk meminimalisir hal-hal yang dirasa kurang baik misalnya, membolos saat pelajaran dimulai, keluar dari wilayah tanpa izin guru/staf yang bertugas, merokok serta perbuatan-perbuatan yang di nilai kurang sesuai dengan budaya di dalam wilayah Siswa SMA. Setiap manusia di mukabumi ini memiliki aturan hidupnya masing-masing, aturan tersebut dinamakan dengan agama.

Agama memiliki peran penting dalam mengendalikan kehidupan manusia, diibaratkan seperti adanya Undang-undang yang mengatur hukum suatu negara, yang diciptakan agar seluruh masyarakat mematuhi peraturan yang sudah ditetapkan 
oleh pemimpinnya, begitu pula Agama agar mereka selamat di dunia dan akhirat. Inilah yang menjadi alasan mengapa dibentuknya bimbingan konseling islam di lembaga pendidikan agar menjadi suatu wadah untuk peserta didik dalam mencurahkan segala permasalahannya untuk mencari solusi yang terbaik bukan hanya dirinya sendiri tetapi juga sekitarnya dan meyakinkan dirinya bahwa setiap kesusahan selalu ada kemudahan yakin dan berserah diri kepada Allah. ${ }^{9}$ Fakta yang terjadi saat ini ketika pelaksanaan bimbingan dan konseling berlangsung banyak manfaat yang diperoleh seperti yang paling menonjol meningkatnya nilai-nilai dan norma keagamaan didalam diri peserta didik baik dilingkungan sekolah maupun diluar.

\section{B. Pembahasan}

\section{Pengertian Bimbingan dan Konseling Islam}

Pengertian bimbingan dibagi menjadi dua, secara istilah dan bahasa. Jika secara istilah bimbingan adalah penunjuk jalan, menunjukkan, mengarahkan dan lain lain. secara bahasa bimbingan adalah suatu langkah yang diberikan kepada seorang manusia untuk memberikan suatu rangsangan pola pikir yang kemudian dapat diimplementasikan baik di dalam ruang lingkup keluarga, lingkungan, atau masyarakat sebagai hasil dari pemahaman yang diperoleh.

Bimbingan dan konseling dalam pandangan islam merupakan usaha yang dilakukan untuk menyelesaikan suatu persoalan yang terjadi dalam diri seseorang dengan berlandaskan norma-norma keislaman. ${ }^{10}$ Peraturan Pemerintah No.29 tahun 1990 mengenai Pendidikan Menengah, Bimbingan adalah upaya secara sadar yang dilakukan kepada individu yang terindikasi memiliki permasalahan maupun

9 Prayitno, Erman Amti. Dasar-dasar Bimbingan dan Konseling (Jakarta: Rineka Cipta, 1999), h. 17

10 Tohirin. Bimbingan dan Konseling di Sekolah dan Madrasah (Jakarta: Rajawali Pers, 2009), h. 16 
untuk menemukan jati dirinya sehingga mampu mengenal lingkungan dan melanjutkan hidupnya dengan baik. ${ }^{11}$

Pengertian bimbingan mengalami perubahan signifikan, jika dulu dikenal dengan istilah penyuluhan yang mengundang banyak pro-kontra karena dilihat dari bahasanya yang sukar dipahami sehingga menjadi perdebatan pendapat. Dari perdebatan yang terjadi dikalangan para ahli dalam mencetuskan definisi bimbingan kemudian diperoleh hasil, yakni bimbingan merupakan proses yang dilakukan oleh pembimbing kepada yang dibimbing untuk meningkatkan potensi baik didalam dirinya dan memperbaiki/mencari solusi terkait permasalahan yang dihadapi agar kelak dapat menjalani proses kehidupan. ${ }^{12}$

Berlanjut pada definisi Konseling dari segi arti yakni dapat dikatakan sebagai petuah, saran, masukan, segala sesuatu yang menyangkut obrolan. ${ }^{13}$ Dalam pengaplikasiannya konseling melibatkan individu-individu yang saling membantu dan saling bertukar pengetahuan yang dimilikinya supaya dari hal tersebut didapatkan hasil konkrit dalam penyelesaian masalah. Konseling dapat pula diartikan sebagai dua individu yang saling bertemu dan\&nbsp; berkonsultasi terkait masalah yamg sedang dialami kemudian berusaha mencari cara penyelesaian. ${ }^{14}$ Ada juga pendapat dari para ahli yang mengatakan bahwa konseling merupakan rangkaian kegiatan yang dimulai dari ahli konseling memberikan arahan dan nasehat kepada individu, lalu individu tersebut menguraikan apa dan bagaimana permasalahan yang sedang dihadapi, kemudian pada

11 Salahudin, Anas. Bimbingan dan Konseling (Bandung: Pustaka Setia, 2010), h. 15

${ }^{12}$ Hamdi Abdul Karim, Manajemen Pengelolaan Bimbingan Pranikah Dalam Mewujudkan Keluarga Sakinah, Mawaddah, wa Rahmah, Jurnal Bimbingan Penyuluhan Islam Vol. 1 No. 2 Juli-Desember 2019 h 326

13 Sukardi, ketut dewa. Pengantar Pelaksanaan Program Bimbingan dan Konseling di Sekolah (Jakarta: Rineka Cipta, 2010), h. 37

14 Tohirin. Bimbingan dan Konseling di Sekolah dan Madrasah (Jakarta: Rajawali Pers, 2009), h. 22 
akhirnya disepakati solusi yang tepat untuk menyikapi masalah tersebut. 15

Jadi dapat ditarik kesimpulan bahwa bimbingan dan konseling yaitu solusi yang diberikan kepada individuindividu yang sedang mengalami permasalahan, solusi yang diberikan itupun sesuai dengan situasi dan kondisi fisik dan psikomotorik individu tersebut. Dalam bimbingan dan konseling islam memiliki kaidah-kaidah tersendiri, menyikapi permasalahan individu lebih diarahkan kepada nilai-nilai islam dengan mendalami ilmu agama, dengan begitu individu akan merasakan ketenangan didalam jiwa dan hati nya sehingga akan menghasilkan pola pikir yang tepat untuk masalahnya. ${ }^{16}$

Bimbingan dan konseling islam mengupayakan setiap individu yang menjadi klien dapat mengembangkan kemampuannya dalam hal pola pikir, menanggapi permasalahan dan memikirkan/menyusun masadepan yang terarah sesuai dengan petunjuk dari Allah agar selalu mendapatkan kemudahan didunia dan di akhirat . ${ }^{17}$ Kegiatan yang dilakukan oleh individu untuk meningkatkan kemampuan dirinya dan kodratnya sebagai umat muslim meningkatkan bakatnya, oleh karena itu Allah memberikan manusia berupa akal, hati dan kemauan manusia untuk berubah sesuai dengan syariat islam agar manusia berada di jalan kebenaran. ${ }^{18}$

Ketentuan yang telah Allah berikan kepada umat manusia diharapkan agar manusia senantiasa hidup tentram dan damai sehingga tidak menimbulkan penyakit didalam hatinya yang menyebabkan kurangnya rasa syukur terhadap

15 Prayitno, Erman Amti. Dasar-Dasar Bimbingan dan Konseling (Jakarta: Rineka Cipta, 1999), h. 105

16 Mubarok, Ahmad. Teori dan Kasus, cetakan I (Jakarta: Bina Rena Pariwara, 2000), h. 4

17 Lubis, Syaiful Akhyar. Konseling Islami (Yogyakarta: eLSAQ Press, 2007), h. 98

18 Sutoyo, Anwar. Bimbingan dan Konseling Islami (teori dan praktik) , (Yogyakarta: Pustaka Pelajar, 2013), h. 22 
kehidupannya. ${ }^{19}$ Dengan berbagai pendapat yang dikemukakan oleh para ahli di atas dapat ditarik kesimpulan bahwasannya yang dinamakan dengan bimbingan konseling islam yaitu kegiatan yang dilakukan dengan sadar melibatkan individu-individu yang memiliki kecenderungan terhadap masalah yang sedang dialami kemudian memberikan solusi dan diaplikasikan sesuai dengan normanorma syariat islam yang berlaku.

\section{Landasan Bimbingan dan Konseling Islam}

Landasan utama bimbingan dan konseling Islam adalah Alquran dan hadits. karena keduanya merupakan sumber dari segala pedoman untuk umat Islam. Diterangkan pada surat Al-isra' ayat 82 , tentang begitu pentingnya Al-quran dalam kehidupan manusia, sehingga beberapa bidang ilmu menjadikan Al-quran sebagai rujukan dan tuntunan. Dalam Al-quran tidak hanya dijelaskan tentang mengatur urusan ibadah saja, akan tetapi dalam Al-quran juga berisi tentang ayat-ayat yang berhubungan dengan penyelesaian pada segala suatu permasalahan yang ada dalam kehidupan manusia. Diantaranya ayat Al-quran yang me ilmu pengetahuan seperti ilmu bimbingan dan konseling Islam sebagai metode bantuan dalam penyelesaian masalahmasalah yang sedang dialami dalam kehidupan manusia. Firman Allah SWT yang diterangkan dalam Al-quran surat Al-Isra': 82.

\section{Tujuan Bimbingan dan Konseling Islam}

Secaragaris besar tujuan bimbingan dan konseling Islam dapat diartikan sebagai gerakan secara nyata untuk membantu individu dalam memwujudkan apa yang diinginkan dirinya sebagai manusia seutuhnya agar dapat mencapai suatu kebahagian didunia maupun diakhirat ${ }^{20}$. Maka untuk mengetahui apa yang harus dilakukan sebagai manusia dan apa yang akan dilakukan dalam berbagai

19 Musnamar,Thohari. Dasar-Dasar Konseptual Bimbingan dan Konseling Islam (Yogyakarta: UII Press, 1992), h. 5

${ }^{20}$ Anton Widodo, Urgensi Bimbingan Penyuluhan Islam Terhadap Pembentukan Keimanan Mualaf, Jurnal Bimbingan Penyluhan Islam Vol.1 No.1 Januari Juni 2019 h 69-71 
bidang kehidupan, merasa lebih baik jauh dari ketegangan dan tekanan terus menerus karena ada persoalan, dapat berfungsi secara maksimal sesuai dengan potensi yang dimiliki, mencapai sesuatu yang lebih baik karena bersikap positif dan optimis, bisa hidup lebih efektif sesuai dengan kemampuan yang dimiliki dan menyesuaikan diri sesuai dengan lingkungan pada dasarnya tujuan bimbingan dan konseling Islam..$^{21}$

Tujuan bimbingan dan konseling Islam terbagi menjadi dua macam yaitu tujuan umum dan tujuan khusus. ${ }^{22}$ Tujuan umum dari bimbingan dan konseling adalah agar individu tersebut dapat mengendlaikan dirinya kearah yang lebih baik untuk mendapakan keridhoan dari Allah SWT. Sedangkan tujuan khusus adalah mencegah agar seseorang tidak mendapatkan suatu masalah, meringankan suatu masalah yang sedang dihadapi seseorang, sehingga seseorang dapat mengontrol suatu situasi dan kondisi agar menjadi lebih baik lagi agar terhindar dari sebuah masalah baik bagi diri sendiri maupun orang lain. bimbingan dan konseling islam mempunyai tujuan yaitu agar amal yang dikaruniakan Allah SWT kepada seseorang dapat berkembang dan berguna dengan baik, agar seseorang dapat menjadi pribadi yang kaffah, sehingga apa yang telah dipelajari dapat diterapkan dalam kehidupan sehari-hari, yang tampil dalam melaksanakan tugas kewajiban di bumi, dan taat dalam beribadah serta mematuhi apa yang telah diperintahkan dan menjauhi apapun yang dilarang.

Bimbingan dan konseling Islam bertujuan untuk meningkatkan Iman, Islam, dan Ikhsan individu yang dibimbing hingga menjadi pribadi yang utuh, dan pada akhirnya diharapkan mereka bisa hidup bahagia didunia dan diakhirat. ${ }^{23}$

${ }^{21}$ Gunarsa, Singgih D. Konseling dan Psikoterapi (Jakarta: Gunung Mulia, 2000), h. 27

22 Musnamar,Thohari. Dasar-Dasar Konseptual Bimbingan dan Konseling Islam (Yogyakarta: UII Press, 1992), h. 34

23 Sutoyo, Anwar. Bimbingan dan Konseling Islami (teori dan praktik), (Yogyakarta: Pustaka Pelajar, 2013), h. 205 
Tujuan bimbingan dan konseling Islam adalah yang diutamakan agar dapat menghasilkan suatu perubahan, melakukan reformasi, kesehatan, dan kebersihan jasmani maupun rohani. ${ }^{24}$ Raga menjadi lebih baik, nyaman dan aman, dapat menerima segala sesuatu dengan ikhlas, mendapat penerangan dan juga dari hidayah Allah SWT, kemudian agar seseorang dapat bersikap secara sopan dalam tingkah laku agar dapat menjadi lebih baik untuk dirinya sendiri, kondisi dalam lingkungan keluarga sosial dan sekitarnya, ketiga saat seseorang sudah mendapatkan suatu ilmu mereka mempunyai rasa keterbukaan pada orang disekitarnya, dan yang keempat agar seseorang dapat menghasilkan toleransi Ilahiyah, agar seseorang mampu mengemban suatu tanggung jawab sebagai pemimpin yang arif dan bijaksana.

Berdasarkan dari pendapat tersebut dapat disimpulkan bahwa tujuan bimbingan dan konseling Islam adalah untuk membantu agar suatu masalah dapat diselesaikan tentunya dengan cara menghidupkan kembali rasa percaya terhadap Allah SWT, pada dasarnya untuk mwujudkan penyesuaian anatara manusia dan lingungan harus didasari dengan keimanan dan ketakwaan. Berlandaskan keimanan dan ketakwaan tersebut diharapkan menimbulkan keserasian antara fungsi-fungsi kejiwaan dan penyesuaian diri antara manusia dengan lingkungannya atau masyarakat yangakan terwujud dan tercapai apabila usaha ini didasarkan keimanan dan ketakwaan kepada Allah SWT.

\section{Fungsi Bimbingan dan Konseling Islam}

Kedudukan bimbingan dan konseling di lembaga pendidikan formal maupun non-formal menjadi penting, karena proses kegiatan belajar mengajar melibatkan guru dan peserta didik yang saling berinteraksi. dari interaksi ini dapat diketahui bagaimana sikap dan perilaku peserta didik selama kegiatan belajar di sekolah maupun ketika diluar. Bimbingan konseling islam memiliki tiga fungsi yang penting seperti

24 Adz Dzaky, Hamdani Bakran. Psikoterapi Konseling Islam (Yogyakarta: Fajar Pustaka Baru,1988), h. 167 
pencegahan dari hal-hal negatif, langkah perbaikan diri, dan pengembangan fitrah individu. ${ }^{25}$

Jika dilihat dari fungsi yang pertama yakni pencegahan yang dilakukan untuk menghambat adanya masalah dan halhal negatif yang datang. Fungsi yang kedua yakni perbaikan dilakukan setelah individu mengalami masalah tersebut kemudian diarahkan kembali agar tidak mengulangi kesalahan tersebut. Fungsi yang ketiga yaitu berusaha menggali dan mengembangkan bakat individu. Pendapat lain mengemukakan ada lima fungsi dari bimbingan konseling yakni Pertama, fungsi pencegahan dilakukan pada saat belum mengalami permasalah hal ini dilakukan untuk mengantisipasi dan melakukan langkah langkah agar terhindar dari masalah. Kedua, fungsi pemahaman yang dilakukan untuk membangun tingkat pemahaman peserta didik dalam berfikir dan bertindak dengan benar. Ketiga, fungsi pengentasan sebagai upaya yang dilakukan untuk menyelesaikan permasalahan yang dialami oleh peserta didik dengan sebijak mungkin. Keempat, pemeliharaan dilakukan ketika pengalaman positif peserta didik selama ini dikembangkan dengan baik. Kelima, fungsi penyaluran yang dilakukan bimbingan konseling ini mengarahkan peserta didik terhadap minat dan kemampuannya kemudian diberikan suport penuh agar termotivasi untuk mendapatkan hasil yang memuaskan.

\section{Metode dan Teknik Bimbingan dan Konseling Islam}

Salah satu cara yang diberikan seorang penasihat ketika memberikan ide atau saran kepada seseorang dalam rangka pelaksanaan bimbingan dan konseling Islam menggunakan suatu metode bimbingan kelompok dan konseling. Yang dimaksudkan dalam bimbingan kelompok dimna seseoraaang ingin mengatasi suatu persoalan-persoalan dengan cara mengikuti kegiatan dalam mengatasi masalah atau persoalan-persoalannya dengancara pemecahan melalui kegiatan-kegiatan kelompok merupakan metode dan teknik

${ }^{25}$ Faqih, Ainur Rahim. Bimbingan Konseling dalam Islam (Jakarta: pers, 2001), h. 37 
bimbingan dan konseling Islam. Beberapa teknik bimbingan: ${ }^{26}$

a. Teknik bimbingan yang terdiri dari sekelompok orang dalam suatu pertemuan, dengan satu orang pembimbing yang bertanggung jawab penuh terhadap kelompok tersebut dinamakan home roomprogram.

b. Suatu teknik bimbingan dimana hal tersebut berfungsi sebagai rekreasi dan kegiatan belajar dinamakan karya Wisata.

c. Suatu cara dimana seseorang dapat menyampaikan masalahnya dan bersama-sama mencari jalan keluar dari masalah tersebut dinamakan diskusi kelompok.

d. Dimana individu-individu yang dibimbing diberi kesempatan untuk dapat merencanakan sesuatu dan mengerjakannya secara bersama-sama dinamakan kerja kelompok.

e. Teknik bimbingan untuk mencari suatu pemecahan masalah yang dihadapi oleh individu sehubungan dengan konflik-konflik psikis mereka dinamakan psikodrama. f) Teknik dalam bimbingan untuk memecahkan masalah sosial yang dihadapi oleh individu dengan jalan bermain peran dinamakan sosiodrama yaitu.

f. Bentuk bimbingan yang diberikan kepada individu untuk membantu memecahkan kesulitan-kesulitan belajar yang mereka hadapi dinamakan Remidial teaching.

Selain pelayanan bimbingan kelompok juga ada bimbingan secara individu yang biasa disebut dengan istilah konseling. Pada umumnya bimbingan individu ada tiga teknik yaitu directive counseling, non directive counseling, dan Electif counseling. ${ }^{27}$ Directive counseling adalah seorang penasihat akan lebih aktif dalam menyampaikan ide kepada konsultan, antara lain dengan cara membimbing seorang klien sesuai dengan masalah apa yang akan diselesaikan. Non directive counseling dalam teknik ini penasihat hanya

26 A. As'ad Djalali. Teknik-Teknik Bimbingan dan Penyuluhan, (Surabaya: Bina Ilmu,1986), h. 58-62

27 Ibid., h. 58-62 
mendengarkanapa uang dikatakan klien sehingga pada teknik ini klien lebih aktif, sedangkan penasihat akan lebih banyak memberikan pengarahan. Electif counseling teknik ini adalah kombinasi dari kedua teknik yang djelaskan diatas, pada bimbingan dan konseling, penasihat akan dapat memutuskan cara apakah yang tepat digunakan pada konseling tentunya sesuia dengan yang dibutuhkan klien dan sesuai dengan ajaran islam.

\section{Pengertian Religiusitas}

Dalam Kamus Besar Bahasa Indonesia bahwa religiusitas bentuk baku dari religiositas yang berarti pengabdian terhadap agama atau kesalehan.Religiusitas berasal dari bahasa latin Religioyang berarti agama, kesalehan, jiwa keagamaan. Sedangkan religiusitas mengukur seberapa jauh pengetahuan, seberapa kokoh keyakinan, seberapa banyak pelaksanaan ibadah dan kaidah, dan seberapa dalam penghayatan atas agama yang di anutnya sehingga religiusitas dapat diartikan sebagai kualitas keagamaan. ${ }^{28}$

Perkumpulan suatu tradisi kumulatif yang didalamnya semua pengalaman dimasa lalu dikumpulkan kemudian dijadikan suatu sistem yang bersifat kebudayaan kemudian diartkan menjadi religion.

Religi yang dimaksut itu dapat menyatukan dan memfokuskan seluruh cinta serta hasrat seseorang agar mau bersama-sama menuju ilahi. ${ }^{29}$ Dari uraian di atas dapat disimpulkan bahwa religiusitas adalah intensitas pendalaman keagamaan seseorang dan keyakinan akan adanya allah SWT yang akan terkabul apabla menjauhi larangannya dan mematuhi perintahannya tentunya dengan jiwa raga yang tulus. Religiusitas disebut penghayatan keagamaan dan pendalaman pada kepercayaan kemudiab ditunjukan dengan cara mengerjkan apa yang telah diwajibkan seperti shalat

${ }_{28}^{8}$ Nashori, Fuad dan Rachma Diana Mucharam. Mengembangkan Kreatifitas dalam Perspektif Psikologi (Yogyakarta:Menara Kudus,2002), h. 71

29 Cremers, Agus. Tahap-Tahap Perkembangan Kepercayaan (Yogyakarta: Kasinus,1995), h. 47 
lima waktu, berdzikir, mengumandangkan ayat suci AlQuran. ${ }^{30}$

Keanekaragaman atau religiusitas ditanamkan didalam bebagai sisi kehidupan mahluk hidup. aktivitas suatu keagamaan tidak hanya dilakukan ketika seseorang sedang melakukan kegiatan ibadah, bukan juga kegiatan yang dapat dilihat ataupun tidak dapat dilihat oleh mata, akan tetapi juga kegiatan tidak ada hubungannya dengan isi hati seseorang. Dikarenakan keberagamaan suatu seseorang akan meliputi berbagai macam sisi atau dimensi.

\section{Analisis Pelaksanaan Bimbingan dan Konseling Islam dalam Meningkatkan Religiusitas Siswa di SMA (Sekolah Menengah Atas)}

Adanya layanan bimbingan dan konseling Islam disekolah dapat dijadikan sebagai metode oleh guru dalam memberikan bimbingan dan motivasi kepada siswa sesuai dengan ajaran Al-quran dan Hadis dengan menerapkan nilainilai keagamaan sebagai pegangan atau landasan siswa dalam mengatasi segala permasalahan yang di hadapinya. Kurangnya pemahaman keagamaan menjadi salah satu faktor timbulnya perilaku menyimpang terhadap remaja, itu bisa terjadi ketika individu tidak memiliki dasar agama yang kuat sehingga mudah terpengaruh oleh kondisi lingkungan sekitar, maka perlu adanya proses pendampingan belajar dan pendidikan keagamaan. Harapanya adalah agar individu dapat terhindar dari perilaku menyimpang yang biasanya muncul dari pengaruh lingkungan sekitar. Arah yang ditempuh adalah menuju pengembangan fitrah dan kembali kepada fitrah. ${ }^{31}$ Berdasarkan temuan dilapangan sebagaimana hasil wawancara tentang pelaksanaan bimbingan dan konseling Islam, dapat diketahui bahwa keberadaan bimbingan dan konseling Islam sangat dibutuhkan, baik oleh

${ }^{30}$ Hawari, D. Al-Qur'an: Ilmu Kedokteran Jiwa dan Kesehatan Jiwa (Jakarta: Dana Bhakti Prima Yasa, 1996), h. 23

31 Sutoyo, Anwar. Bimbingan dan Konseling Islami (teori dan praktik), (Yogyakarta: Pustaka Pelajar, 2013), h. 23 
pihak sekolah sebagai pengembangan mutu di Di Sekolah Menengah Atas (SMA).

Melihat pentingnya bimbingan dan konseling Islam sebagaimana diatas, maka bimbingan dan konseling Islam adalah bagian dari sebuah kehidupan manusia. Artinya dalam kehidupannya sehari-hari manusia tidak terlepas dari masalah. Banyak orang dapat menyelesaikan masalahnya sendiri tanpa melibatkan orang lain, namun tidak sedikit orang yang tidak dapat mengatasi masalahnya dan meminta bantuan kepada orang lain untuk membantu memecahkan dan memberikan solusi hal ini juga terjadi pada siswa di Sekolah Menengah Atas (SMA). Hasil penelitian di Sekolah Menengah Atas (SMA) menunjukan bahwa pelaksanaan bimbingan dan konseling Islam dalam meningkatkan religiusitas siswa di fokuskan pada materi dan metode. Pelaksanaan Bimbingan konseling Islam dalam meningkatkan religiusitas di Sekolah Menengah Atas (SMA) terdapat kesesuaian antara teori dan praktik terhadap tingkat religiusitas meliputi berbagai macam sisi atau dimensi dalam pemberian materi-materi yang sesuai dengan aspek-aspek atau dimensi religiusitas seperti dimensi keyakinan, dimana perseta didik diajarkan untuk meyakin kebenarankebenaran dalam ajaran Agama Islam, seperti percaya kepada Allah, surga dan neraka, qadha dan qadar dan hal-hal lain yang berkaitan dengan ajaran Agama. Kemudian dimensi praktik agama dimana siswa dibimbing dengan materi yang berkaitan tentang ibadah mahdhah dan ghairu mahdhah seperti shalat, puasa, dan ibadah yang berhubungan dengan sesama manusia, dapat menjalan ibadah dengan baik dan benar atau khusyu", serta diberikan pemahaman bahwa kegiatan ibadah yang dilakukan merupakan salah satu cara untuk mendekatkan diri kepada Allah, dan sebagai sarana doa agar setiap doa bisa terkabulkan yang termasuk juga dalam dimensi pengalaman. Kemudian dimensi pengamalan atau konsekuensi yang disejajarkan dengan akhlak juga diterapkan kepada siswa salah satunya yang sudah menjadi budaya di Sekolah Menengah Atas (SMA) adalah tawadhu", dengan satu penerapan sikap tawadhu " tersebut sudah mewakili seluruh aturan sikap harus terapkan dan dibiasakan oleh siswa.

Kajian Agama yang dilakukan dengan kerjasama dengan Guru Agama sehingga dapat memberikan 
pengetahuan lebih tentang Agama. Dan di Sekolah Menengah Atas (SMA) diterapkan pengawsan penuh dalam waktu 24 jam agar dapat memantau perkembangan siswa dan yang melanggar aturan maka disinilah konsekuensi yang dijalankan seperti memberikan pembinaan yang berkaitan dengan ibadah agar selain siswa sadar dengan kesalahanya, siswa juga tetap mendapat hikmah pahala yang dilakukan. Materi terkait peningkatan religiusitas siswa di Sekolah Menengah Atas (SMA) agar dapat memiliki keyakinan agama yang kuat yang termanifestasi melalui tindakan ibadah yang istiqomah dan akhlak yang mulia sebagai wujud pengamalan dan penghayatan dari adanya pengetahuan terhadap ajaran agama Islam. Materi yang di sampaikan guru BK pada saat melakukan bimbingan secara umum mencerminkan nilai-nilai Iman, Islam, Ihsan. Hal ini sesuai dengan pendapat sutoyo mendorong dan membantu individumemahami dan mengamalkan Iman, Islam, Ihsan. 32

Hakikat bimbingan konseling Islam adalah upaya membantu individu belajar mengembangkan fitrah dan atau kembali kepada fitrah dengan cara memperdayakan Iman, akal, dan kemauan yang dikaruniakan Allah SWT kepada umatnya untuk mempelajari tuntutan Allah dan rasulNya, agar fitrah yang ada pada individu itu berkembang dengan benar dan kukuh sesuai tuntutan Allah SWT. 33 Bimbingan dan Konseling Islam adalah proses pemberian bantuan terhadap individu agar mampu hidup selaras dengan ketentuan dan petunjuk Allah, sehingga dapat mencapai kebahagiaan didunia dan diakhirat. ${ }^{34}$ Pada dasarnya mengatasi permasalahan yang dialami oleh siswa tidak dapat dilihat dari satu sudut saja, yaitu segi psikologisnya. Namun juga perlu diperhatikan dari segi keagamaan siswa. siswa yang melakukan kenakalan tidak hanya disebabkan karena kurangnya perhatian dari orang tua, tetapi juga dipengaruhi faktor karena kurang tahunya siswa terhadap nilai-nilai ajaran agama untuk mendorong dan membantu individu

32 Ibid., h, 214

33 Ibid., h, 22

34 Musnamar,Thohari. Dasar-Dasar Konseptual Bimbingan dan Konseling Islam (Yogyakarta: UII Press, 1992), h. 5 
memahami dan mengamalkan ajaran agama secara benar. ${ }^{35}$ Dalam hal ini konselor mengingatkan kepada individu bahwa untuk selamat dunia akhirat maka ajaran agama harus dijadikan pedoman dalam setiap langkahnya, Sehingga selain mendapatkan penanganan dari guru BK melalui pendekatan psikologis, siswa juga membutuhkan bimbingan agama dari orang yang ahli agama yaitu guru agama untuk mengajarkan nilai-nilai agama sebagai pedoman dalam hidupnya. Ditinjau dari hal ini, maka disinalah antara guru guru agama dan guru BK dapat melakukan gubungan kerjasama yang baik sesuai dengan ranahnya.

\section{Penutup}

Pelaksanaan bimbingan dan konseling di Sekolah Menengah Atas (SMA) dalam meningkatkan religiusitas siswa lebih difokuskan pada materi dan metode. Pada penyampaian materi khususnya berkaitan dengan dimensi religiusitas, seperti materi berkaitan tentang ibadah mahdhah dan ghairu mahdhah seperti shalat, puasa, dan ibadah yang berhubungan dengan sesama manusia, kemudian terdapat juga bimbingan Akidah, bimbingan Syariah, bimbingan Akhlak, dan materi yang dapat meningkatkan religiusitas siswa lainnya. Sedangkan untuk Metodenya yaitu metode konseling kelompok, konseling individu, metode ceramah. Metode ceramah ini juga terintegrasi dengan kajian agama yang dilakukan pada sore hari dan dibimbing oleh guru agama yang dilaksanakan setiap hari, namun guru BK tetap dalam posisi mengawasi perkembangan tingkah laku para siswanya. Kemudian faktor pendukung tidak hanya dari guru Agama dan lingkungan sekolah saja tetapi juga dari guru BK sendiri. Guru BK di Sekolah Menengah Atas (SMA) tidak hanya memberikan layanan secara umum saja akan tetapi juga menjadi juru dakwah yang bertujuan untuk meningkatkan religiusitas siswa agar siswa dapat memiliki keyakinan agama yang kuat yang terwujud melalui tindakan ibadah yang istiqomah berakhlak yang mulia dan sebagai wujud pengamalan dan penghayatan dari adanya pengetahuan terhadap ajaran agama Islam. Setiap pelaksanaan bimbingan dan konseling yang

35 Sutoyo, Anwar. Bimbingan dan Konseling Islami (teori dan praktik), (Yogyakarta: Pustaka Pelajar, 2013), h. 214 
diberikan oleh guru BK kepada siswa tentunya akan memunculkan dampak dari pelaksanaan tersebut. Begitu juga dampak pelaksanaan bimbingan dan konseling dalam meningkatkan religiusitas siswa di Sekolah Menengah Atas (SMA) sangat beragam bagi siswa yaitu siswa dapat memiliki keyakinan agama yang kuat yang terwujud melalui tindakan ibadah yang istiqomah berakhlak yang mulia dan sebagai wujud pengamalan dan penghayatan dari adanya pengetahuan terhadap ajaran agama Islam.

\section{Daftar Pustaka}

A, As'ad Djalali. Teknik-teknik Bimbingan dan Penyuluhan, (Surabaya: Bina Ilmu,1986)

Adz Dzaky, Hamdani Bakran. Psikoterapi Konseling Islam (Yogyakarta: Fajar Pustaka Baru,1988),

Ancok, Djamaludin. Psikologi Islam (Yogyakarta: Pustaka Pelajar, 1994)

Anton Widodo, Fathur Rohman, Konsep Jiwa Yang Tenang Dalam Surat Al-Fajr Ayat 27-30 (perspektif Bimbingan Konseling Islam), Al-Irsyad: Jurnal Bimbingan Konseling Islam, Vol.1 No 2 Desember 2019

Anton Widodo, Urgensi Bimbingan Penyuluhan Islam Terhadap Pembentukan Keimanan Mualaf, Jurnal Bimbingan Penyluhan Islam Vol.1 No.1 Januari Juni 2019

Cremers, Agus. Tahap-tahap Perkembangan Kepercayaan (Yogyakarta: Kasinus, 1995)

Faqih, Ainur Rahim. Bimbingan Konseling dalam Islam (Jakarta: Pers, 2001)

Geldard, Kathryn dkk. Konseling Remaja Pendekatan Proaktif Untuk Anak Muda (Yogyakarta: Pustaka Belajar, 2010)

Gunarsa, Singgih D. Konseling dan Psikoterapi (Jakarta: Gunung Mulia, 2000)

Hamdi Abdul Karim, Manajemen Pengelolaan Bimbingan Pranikah Dalam Mewujudkan Keluarga Sakinah, Mawaddah, wa Rahmah, Jurnal Bimbingan Penyuluhan Islam Vol. 1 No. 2 Juli-Desember 2019 
Hawari, D. Al-Qur'an: Ilmu Kedokteran Jiwa dan Kesehatan Jiwa (Jakarta: Dana Bhakti Prima Yasa, 1996)

Hemlan Elhany, Dakwah Islam Di Era Golbalisasi Perspektif Bimbingan Penyluhan Islam, Jurnal Bimbingan Penyuluhan Islam, Vol.1 No 1 Januari-Juni 2019

Hikmawati, Fenti. Bimbingan Konseling(edisi Revisi), (Jakarta: Rajawali Pers, 2012),

Lubis, Syaiful Akhyar. Konseling Islami (Yogyakarta: eLSAQ Press, 2007)

Mubarok, Ahmad. Teori dan Kasus, cetakan I (Jakarta: Bina Rena Pariwara, 2000)

Musnamar,Thohari. Dasar-dasar Konseptual Bimbingan dan Konseling Islam (Yogyakarta: UII Press, 1992)

Nashori, Fuad dan Rachma Diana Mucharam. Mengembangkan Kreatifitas dalam Perspektif Psikologi (Yogyakarta:Menara Kudus, 2002)

Prayitno, Erman Amti. Dasar-Dasar Bimbingan dan Konseling (Jakarta: Rineka Cipta, 1999)

Salahudin, Anas. Bimbingan dan Konseling (Bandung: Pustaka Setia, 2010)

Sukardi, ketut dewa. Pengantar Pelaksanaan Program Bimbingan dan Konseling di Sekolah (Jakarta: Rineka Cipta, 2010)

Sutoyo, Anwar. Bimbingan dan Konseling Islami (teori dan praktik), (Yogyakarta: Pustaka Pelajar, 2013)

Tohirin. Bimbingan dan Konseling di Sekolah dan Madrasah (Jakarta: Rajawali Pers, 2009) 
